\title{
Partial mummification and extraordinary context observed in perinate burials: a complex osteoarcheological study applying ICP-AES, $\mu$ XRF, and macromorphological methods
}

\author{
János Balázs ${ }^{1}$ (D) Z Zsolt Bereczki ${ }^{1}$ - Attila Bencsik ${ }^{2}$ - György V. Székely ${ }^{3}$ - László Paja ${ }^{1}$. \\ Erika Molnár ${ }^{1}$ • Ágnes Fogl ${ }^{1}$. Gábor Galbács ${ }^{4}$ - György Pálfi ${ }^{1}$
}

Received: 18 February 2016 / Accepted: 12 September 2016

(C) Springer-Verlag Berlin Heidelberg 2016

\begin{abstract}
Very small, green colored, partially mummified remains of a perinate individual were found buried in a ceramic pot with a copper coin in the Late Medieval cemetery of Nyárlőrinc-Hangár út ("Nyárlörinc 3. lelőhely") in southern Hungary. The remains must date back to the second half of the nineteenth century AD. In this paper; we present data gathered in a series of multidisciplinary investigations targeted to the partially mummified remains (ind. no. 14426) and two other non-mummified perinates (ind. no. 10662 and no. 14336) possibly buried under similar circumstances in the cemetery. Besides standard macromorphological and stereomicroscopic examinations, we compared $\mathrm{Cu}$ concentrations in the remains using ICPAES and mapped $\mathrm{Cu}$ concentration changes using $\mu \mathrm{XRF}$. The partially mummified perinate showed the highest $\mathrm{Cu}$ concentrations, while the individual buried without a possible $\mathrm{Cu}$ source showed the lowest. Body parts in the closer proximity of the copper coins always showed higher concentration. The mummified individual showed 497 times higher $\mathrm{Cu}$ values than average, and even the
\end{abstract}

Gábor Galbács and György Pálfi contributed equally to this work as last authors.

János Balázs

janos.balazs@gmail.com

1 Department of Biological Anthropology, University of Szeged, Hungary, 6726 SzegedKözép fasor 52., Hungary

2 Department of Mineralogy, Geochemistry and Petrology, University of Szeged, Hungary, SzegedEgyetem u. 2., 6722, Hungary

3 Katona József Museum, KecskemétRákóczi út 1., 6000, Hungary

4 Department of Inorganic and Analytical Chemistry, University of Szeged, Hungary, SzegedDóm tér 7., 6720, Hungary perinate buried without copper coin measured higher than the otherwise normal $\mathrm{Cu}$ content of the soil. Extremely high $\mathrm{Cu}$ values may be related to the corrosion of the coins included in the burials. Mummification must have been facilitated by copper deriving from the coins. Uneven $\mathrm{Cu}$ concentrations and only partial mummification of one of the individuals refer to the importance of other environmental factors involved in a possible quasinatural mummification process. However, the Nyárlörinc perinate burial no. 14426 may be the first solely copperdriven mummification case ever reported, and hopefully, more cases are to appear in the future.

Keywords Partial mummification · Copper · ICP-AES · $\mu \mathrm{XRF} \cdot$ Perinate $\cdot$ Pot burial

\section{Introduction}

During data collection in a Late Medieval osteological series of Nyárlőrinc-Hangár út, we have come across very small, green colored remains of a perinate individual that seemed to be partially mummified. Preservation of these minute remains was so good that we decided to invite a specialist of other scientific fields to conduct a series of multidisciplinary investigations on the bones in order to come to a common conclusion concerning these rare findings unparalleled in the bioarcheological record. Mummified human remains are a rarity and the custom of perinate pot burials have never been documented in osteoarcheological series before.

The term "mummy" covers all dead bodies with wellpreserved soft tissues (Cockburn et al. 1998; Quigley 1998; Goffer 2007; Lynnerup 2007), while the process resulting in the preservation of a dead animal's or a 
person's body is called mummification. The process may be spontaneous (natural), anthropogenic (artificial), or a combination of the two (Aufderheide 2003; Lynnerup 2007). The majority of natural mummies are found in dry places such as the sandy soil of deserts or dry caves, where desiccation takes place rapidly (Cockburn et al. 1998; Aufderheide 2003; Józsa 2006; Lynnerup 2007). Natural and artificial mummified archeological findings are equally scarce in Hungary (Susa and Józsa 1995; Aufderheide 2003; Józsa 2006). Most of these cases are intentional anthropogenic mummifications (Susa and Józsa 1995; Józsa 2006) except for the Vác series (Susa and Józsa 1995; Pap et al. 1997). Very few spontaneously mummified corpses are known in the country (Susa and Józsa 1995; Józsa 2006). The most important partially mummified relic is The Holy Right Hand, the mummified right hand of first Hungarian king St. Stephen from the early eleventh cetury AD (Bochkor 1960; Rácz 2013; Kristóf 2015). Perinate individuals have never been described in the Hungarian material.

Copper compounds often cause superficial green coloration on human remains. Soluble copper may also penetrate soft tissues and bones, as confirmed by X-ray fluorescence analysis of the "Copper Man" (New York's American Museum of Natural History) (Cockburn et al. 1998). There are relatively few reliable references in the literature. Data from copper measurements in different bones (Szpunar et al. 1978; Lambert et al. 1979; Shafer et al. 2008) and mummified tissues (Nunnelley et al. 1976; Reyman et al. 1976; Kłys et al. 1999) are summarized in Table 1. While copper is essential for the functioning of some human enzymes (Shafer et al. 2008), it is also known to have antimicrobial character (Cockburn et al. 1998) and its compounds have been used as fungicides and bactericides for many years (e.g., $\mathrm{CuSO}_{4}$, Bordeaux mixture) (Adriano 2001).

Copper and other elements from hair samples are frequently measured in mummy studies to provide nutrition data (Benfer et al. 1978; Sanford et al. 1983; Sandford and Kissling 1994). The determination of trace metals in ancient bones, teeth, and soft tissues is possible and have been described in the literature using several alternative atomic spectroscopy methods, including flame atomic emission spectrometry (Farkas 1972), atomic absorption spectrometry (AAS) (Kłys et al. 1999), synchrotron microprobe and X-ray fluorescence spectrometry (XRF) (Carvalho et al. 2000), inductively coupled plasma atomic emission spectrometry (ICP-AES) (Zlateva et al. 2003), inductively coupled plasma mass spectrometry (ICP-MS) (Degryse et al. 2004), and others.

In this paper, we present data gathered in a series of multidisciplinary investigations targeted to perinate burials with coin offerings possibly deriving from the second half of the nineteenth century $\mathrm{AD}$ found in the Late Medieval cemetery of Nyárlőrinc-Hangár út ("Nyárlőrinc 3. lelőhely") in southern Hungary, with special emphasis on partially mummified remains of a perinate buried in a ceramic pot.

\section{Material and methods}

The partly mummified individual no. 14426 was excavated in Nyárlörinc (Fig. 1), southern Hungary from the twelfth to sixteenth century CE cemetery of Nyárlörinc-Hangár út (Nyárlőrinc 3. lelöhely, id. no. 27955) situated around an twelfth to sixteenth century CE (Árpádian Age) church in a series of excavations between 1982 and 1992 supervised by György V. Székely (V Székely 1987; Balázs et al. 2005). The excavations yielded 541 graves mainly from the twelfth to sixteenth centuries, but occasional solitary burials took place in the site until the mid nineteenth century when the walls of the ruined church were still standing (Balázs et al. 2005).

Some of the excavated graves contained no human remains while others housed multiple burials (Balázs et al. 2005). Osteoarcheological investigation was carried out involving the remains of altogether 483 individuals (Balázs 2005; Bölkei 2005). The Nyárlörinc series has already furnished important paleopathological (e.g., syphilis, skeletal tuberculosis) and paleomicrobial data (Pálfi et al. 1997, 2009; Molnár et al. 1998; Balázs et al. 2005, 2015; Marcsik et al. 2006).

The mummified remains were buried in a ceramic pot (Fig. 2) near the edge of the cemetery. The date of this unique funeral can be approximated on the basis of a copper coin ("Kreuzer or krajcár") found right next to the remains. This particular type of coin was in circulation between 1858 and 1862 (Unger 1997). The pot burial took place at least 150 years after the cemetery has been abandoned (Balázs et al. 2005); thus, the remains of this individual are not part of the Late Medieval series. Preliminary results of the investigations targeted to the mummified remians were presented in 2007 (Balázs and Bölkei 2007).

The partially mummified remains (no. 14426) were analyzed together with the bone remains of two other nonmummified individuals (no. 1062 and no. 14336) possibly buried under similar circumstances in the cemetery. Thorough macromorphological and stereomicroscopic examination was performed on all three individuals. Age at death was determined using the method and definitions of Kósa (1989).

Non-mummified status of the other two individuals implies different chemical conditions not favoring preservation of soft tissues. To test this assumption, we applied state-of-the-art measuring techniques to determine the copper content of the remains. In case of liquid sampling analytical methods, the samples first need to be subjected to acid digestion in order to bring bone samples into solution; thus, these methods are highly invasive. Even though AAS would be a possible tool to 
Table $1 \mathrm{Cu}$ concentrations from the literature measured in different tissues, bone, resin and soil in dry weight $\%$

\begin{tabular}{|c|c|c|}
\hline & $\begin{array}{l}\mathrm{Cu} \text { concentration } \\
\text { in dry weight } \%\end{array}$ & Reference \\
\hline \multicolumn{3}{|l|}{ Tested specimen-mummified } \\
\hline PUM I. soft tissue & 0.00019 & Reyman et al. 1976 \\
\hline PUM I. long bone & 0.00023 & \\
\hline PUM II. muscle & $0.00041 \pm 0.00003$ & Nunnelley et al. 1976 \\
\hline PUM II. skin & $<0.0002$ & \\
\hline PUM II. tendon & $0.00034 \pm 0.00003$ & \\
\hline PUM II. resin & $0.00058 \pm 0.00004$ & \\
\hline hair from Sudan & $0.00124-0.00166$ & Sandford and Kissling 1994 \\
\hline Iset Iri Hetes teeth & 0.00128 & Kłys et al. 1999 \\
\hline Iset Iri Hetes nails & 0.00081 & \\
\hline Iset Iri Hetes bones & 0.00238 & \\
\hline \multicolumn{3}{|l|}{ Tested specimen—non mummified } \\
\hline 20 year or older individuals from Gibson & $0.00075 \pm 0.00016$ & Szpunar et al. 1978 \\
\hline Rib from Gibson & $0.00106 \pm 0.00075$ & Lambert et al. 1979 \\
\hline Rib from Ledders & $0.00105 \pm 0.00023$ & \\
\hline Males from Gibson & $0.00090 \pm 0.00028$ & \\
\hline Females from Gibson & $0.00082 \pm 0.00025$ & \\
\hline Males from Ledders & $0.00103 \pm 0.00012$ & \\
\hline Females from Ledders & $0.00100 \pm 0.00023$ & \\
\hline $0-3$ years children from Gibson & $0.00162 \pm 0.00120$ & \\
\hline Exhumate bones & $0.00013-0.00020$ & Kłys et al. 1999 \\
\hline Iron Age bones (soil-corrected) & 0.000595 & Shafer et al. 2008 \\
\hline \multicolumn{3}{|l|}{ Tested specimen—other } \\
\hline Modern muscle & $0.00018 \pm 0.00008$ & Nunnelley et al. 1976 \\
\hline Mammalian muscle & 0.00031 & \\
\hline Mound from Gibson & $0.00077-0.00127$ & Lambert et al. 1979 \\
\hline Soil & $\begin{array}{l}0.0002-0.0250 \\
\quad \text { (average value } 0.0030 \text { ) }\end{array}$ & Adriano 2001 \\
\hline Burial soils & $0.00255-0.00268$ & Shafer et al. 2008 \\
\hline
\end{tabular}

estimate the concentration of copper from bone and soil samples, because of the minute size of the mummified remains, neither AAS nor some non-invasive examinations (e.g., CT) were possible to perform.
Fig. 1 Map of Hungary showing the location of the site

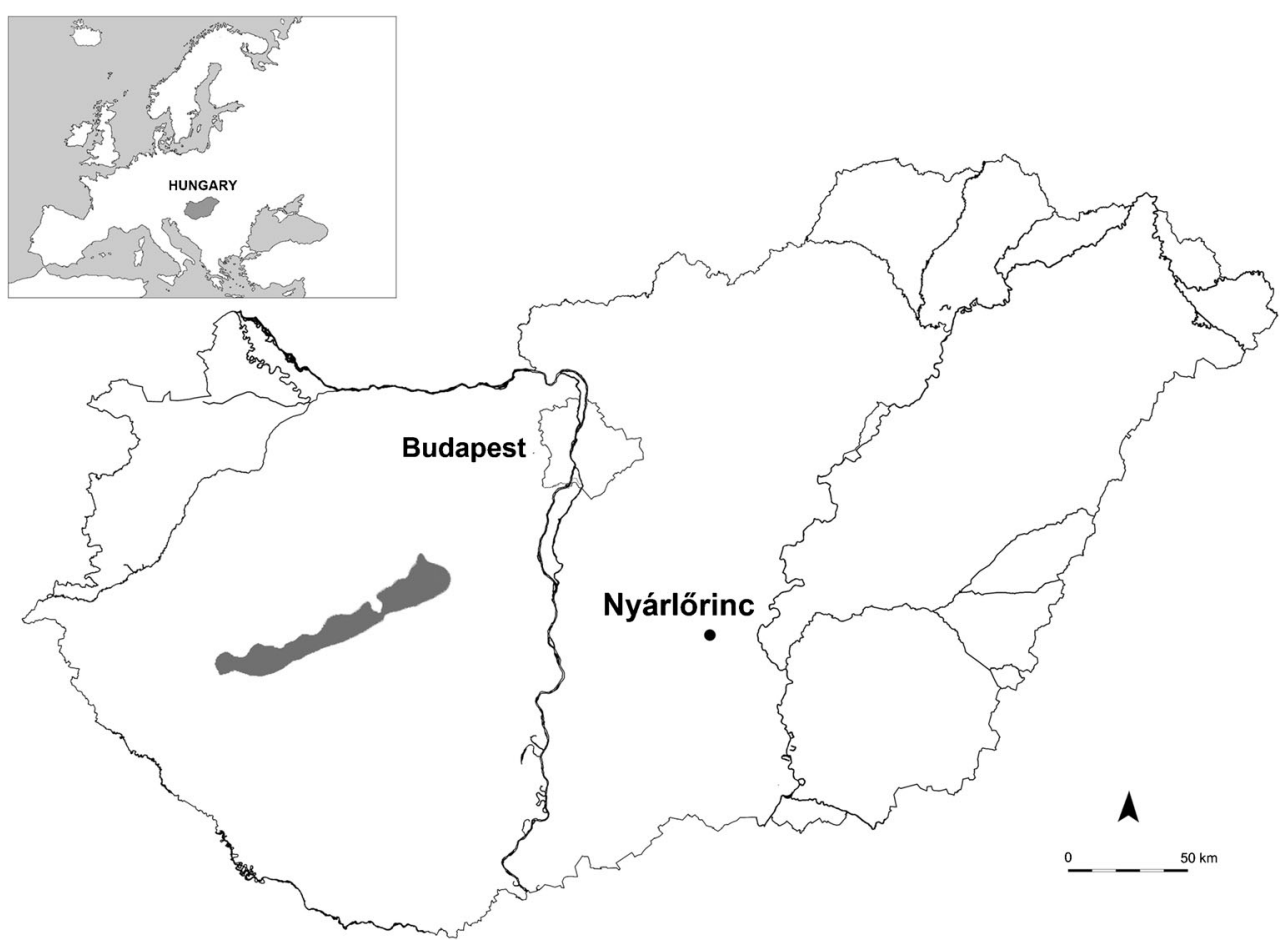


Fig. 2 The ceramic pot where the Nyárlörinc, ind. no. 14426, was buried in

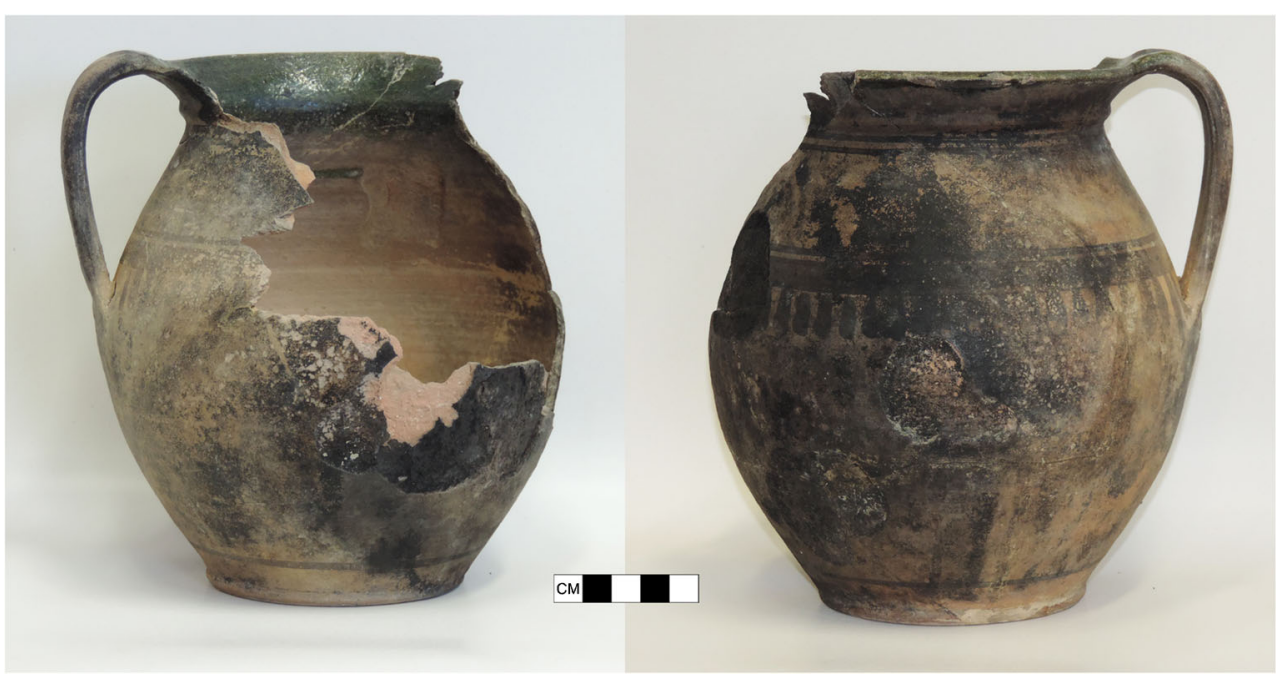

Instead of these, XRF and ICP-AES techniques were applied to measure $\mathrm{Cu}$ concentrations in the remains. $\mu \mathrm{XRF}$ was used for measuring and mapping copper within the remains. The elemental composition was measured

Table 2 Measurements, calculated age, length, and weight of the Nyárlőrinc perinates (using Fazekas and Kósa 1978 and Kósa 1989)

\begin{tabular}{|c|c|c|c|c|}
\hline & \multirow{2}{*}{$\begin{array}{l}\text { Measurements } \\
\text { Length (m) }\end{array}$} & \multicolumn{3}{|c|}{ Calculated data } \\
\hline & & Lunar month & Body length (m) & Body weight $(\mathrm{kg})$ \\
\hline 14426 right humerus & 0.041 & 6.5 & 0.310 & $0.520-0.770$ \\
\hline 14426 left humerus & 0.041 & 6.5 & 0.310 & $0.520-0.770$ \\
\hline 14426 right radius & - & - & - & \\
\hline 14426 left radius & 0.034 & 6.5 & 0.358 & $0.770-0.910$ \\
\hline 14426 right ulna & - & - & - & \\
\hline 14426 left ulna & 0.038 & $6.5-7$ & 0.313 & $0.520-0.770$ \\
\hline 14426 right femur & 0.044 & $6.5-7$ & 0.287 & $0.400-0.510$ \\
\hline 14426 left femur & 0.044 & $6.5-7$ & 0.287 & $0.400-0.510$ \\
\hline 14426 right tibia & 0.039 & $6.5-7$ & 0.287 & $0.400-0.510$ \\
\hline 14426 left tibia & - & - & - & - \\
\hline 14426 right fibula & 0.038 & $6.5-7$ & 0.293 & $0.510-0.560$ \\
\hline 14426 left fibula & 0.038 & $6.5-7$ & 0.293 & $0.510-0.560$ \\
\hline 14426 maxilla & - & - & - & - \\
\hline 14426 mandible & 0.029 & $5.5-6$ & 0.310 & $0.520-0.770$ \\
\hline 10662 right humerus & 0.038 & $5.5-6$ & 0.288 & $0.380-0.510$ \\
\hline 10662 left humerus & 0.037 & $5.5-6$ & 0.280 & $0.380-0.510$ \\
\hline 10662 right radius & 0.031 & $5.5-6$ & 0.326 & $0.520-0.620$ \\
\hline 10662 left radius & 0.030 & $5.5-6$ & 0.316 & $0.520-0.620$ \\
\hline 10662 right ulna & 0.034 & $5.5-6$ & 0.281 & $0.380-0.510$ \\
\hline 10662 left ulna & 0.034 & $5.5-6$ & 0.281 & $0.380-0.510$ \\
\hline 10662 right femur & - & - & - & - \\
\hline 10662 left femur & 0.042 & 6.5 & 0.274 & $0.320-0.450$ \\
\hline 10662 right tibia & - & - & - & - \\
\hline 10662 left tibia & 0.036 & 6 & 0.265 & $0.320-0.340$ \\
\hline 10662 right fibula & - & - & - & - \\
\hline 10662 left fibula & 0.035 & 6 & 0.262 & $0.320-0.340$ \\
\hline 10662 maxilla & 0.014 & $6-6.5$ & 0.287 & $0.380-0.510$ \\
\hline 10662 mandible & 0.031 & $6-6.5$ & 0.316 & $0.520-0.620$ \\
\hline 14334 right humerus & 0.050 & 8 & 0.378 & $0.820-0.980$ \\
\hline 14334 left humerus & 0.050 & 8 & 0.378 & $0.820-0.980$ \\
\hline 14334 right radius & 0.040 & 8 & 0.422 & $1.510-1.940$ \\
\hline 14334 left radius & - & - & - & - \\
\hline 14334 right ulna & 0.047 & $8-8.5$ & 0.387 & $0.950-1.150$ \\
\hline 14334 left ulna & 0.047 & $8-8.5$ & 0.387 & $0.950-1.150$ \\
\hline 14334 right femur & 0.054 & $7.5-8$ & 0.352 & $0.770-0.910$ \\
\hline 14334 left femur & 0.054 & $7.5-8$ & 0.352 & $0.770-0.910$ \\
\hline 14334 right tibia & 0.049 & $8-8.5$ & 0.359 & $0.770-0.910$ \\
\hline 14334 left tibia & - & - & - & - \\
\hline 14334 right fibula & - & - & - & - \\
\hline 14334 left fibula & - & - & - & - \\
\hline 14334 maxilla & 0.018 & $7.5-8$ & 0.370 & $0.820-0.980$ \\
\hline 14334 mandible & 0.039 & 8 & 0.403 & $1.200-1.460$ \\
\hline
\end{tabular}




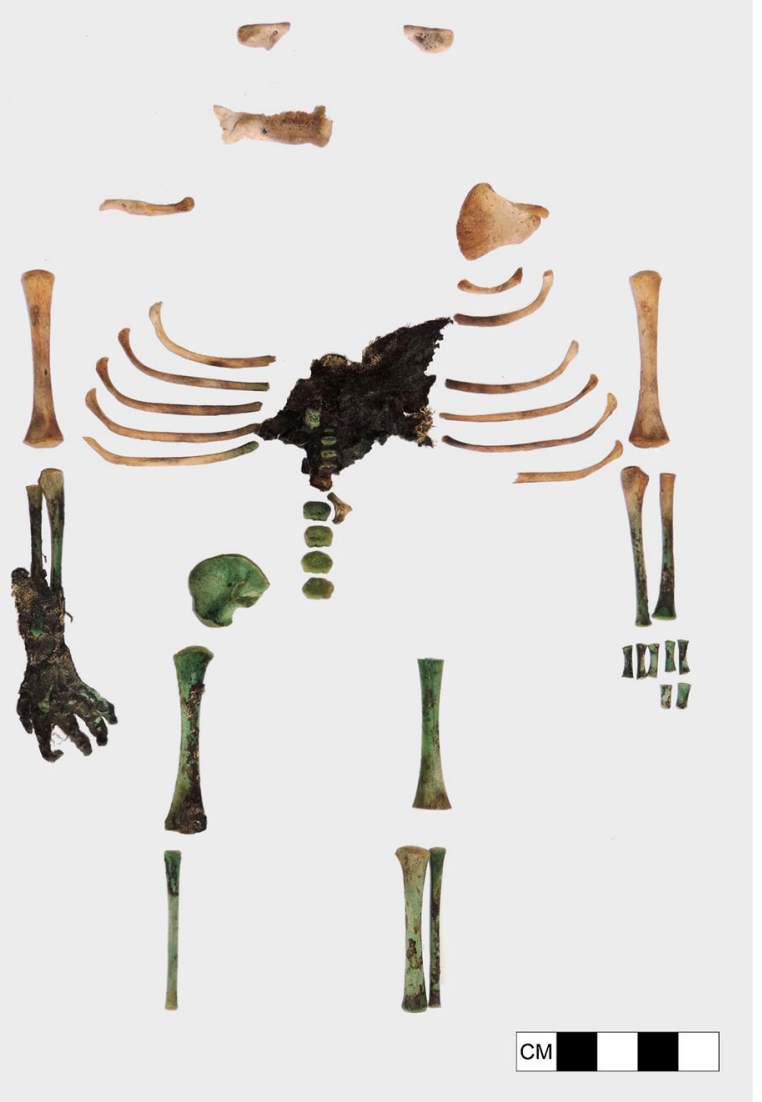

Fig. 3 Nyárlőrinc, ind. no. 14426, skeletal elements, mummified right forearm, and dorsum

with a Horiba Jobin Yvon XGT-5000 Micro X-ray fluorescent spectrometer $(\mu \mathrm{XRF})$, equipped with a $R h \mathrm{X}$-ray source. The $\mu \mathrm{XRF}$ technique is suitable for the qualitative and quantitative determination of major and minor elements from sodium to uranium (Beckhoff et al. 2006). The instrument is able to identify the lateral distribution of chosen elements with $10-\mu \mathrm{m}$ spatial resolution. Measurements were made at $30-\mathrm{kV}$ excitation voltage, 0.5 -mA anode current, and 1800-s measuring time.

ICP-AES measurements were carried out with liquid sample introduction; thus, ca. $0.1 \mathrm{~g}$ of each bone, carefully weighed on an analytical balance, was acid-digested by employing $4 \mathrm{~mL} \mathrm{1:1} \mathrm{diluted} \mathrm{HNO}_{3}$ (Suprapur grade trace analytical quality, Merck) in acid-cleaned, dry polypropylene vessels (VITLAB No. 130394, GL40, $60 \mathrm{~mL}$ ) prior to analysis. The digestion took an hour at $70-80{ }^{\circ} \mathrm{C}$ in a heating block (Kutesz 660 type). The digestion was complete-only a very small amount of suspended matter were left in the solution. The solution was then quantitatively transferred to acid-cleaned polymethylpentene (PMP) volumetric flasks. All rinsing and dilutions were carried out by trace analytical quality deionized labwater

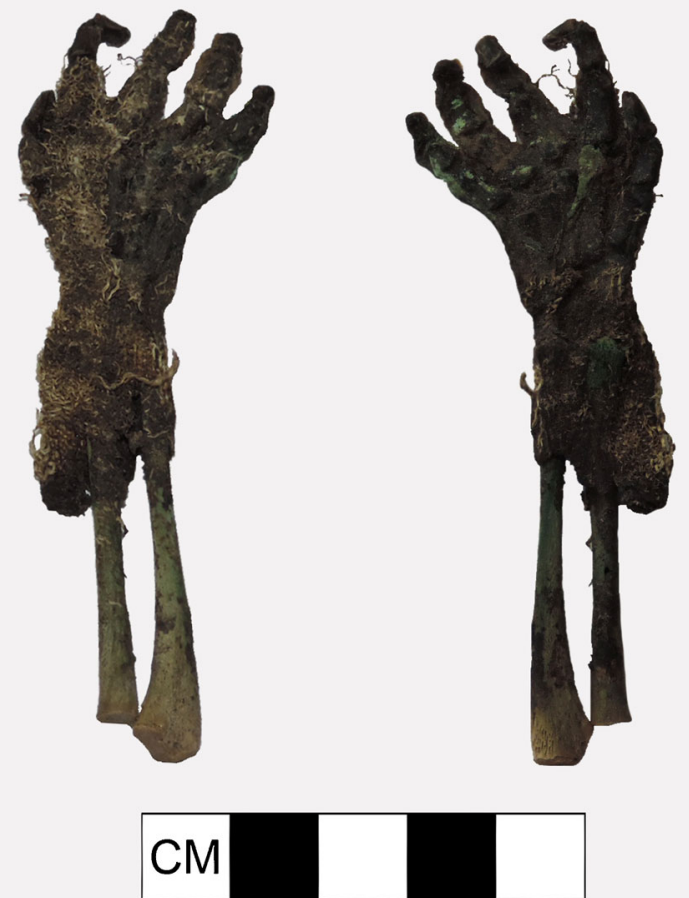

Fig. 4 Nyárlörinc, ind. no. 14426, right forearm, from two angles. The mummified parts and the bones of the forearm show green coloration from the coin offering

(Millipore MilliQ). ICP-AES analysis was performed using an all-argon sequential ICP-AES spectrometer (Jobin-Yvon 24), equipped with a sample introduction system consisting of a Teflon V-groove nebulizer, a Scott double-pass spray chamber, and a Gilson MiniPuls III multi-roller peristaltic pump. The quantitative copper determination was performed at two wavelengths $(\mathrm{Cu} \mathrm{I}$ $324.75 \mathrm{~nm}$ and $\mathrm{Cu}$ I $327.39 \mathrm{~nm}$ ) using four-point calibration plots and two-sided background correction, also employing Gauss fitting for drift-correction. $\mathrm{Cu}$ calibrating solutions were diluted from a $1000 \mathrm{mg} / \mathrm{L}$ monoelement stock solution (Merck Certipur).

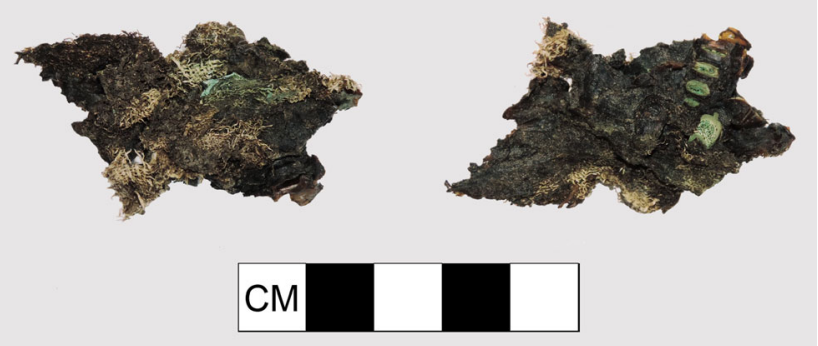

Fig. 5 Nyárlörinc, ind. no. 14426, mummified skin from the dorsal region with five embedded vertebral bodies shown from two angles. The mummified soft tissue inseparably sticks to the remains of the textile that the body was wrapped in 


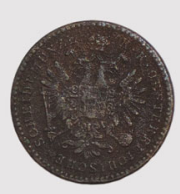

a

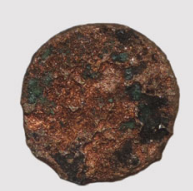

b

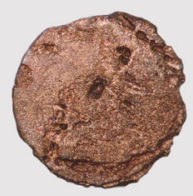

C

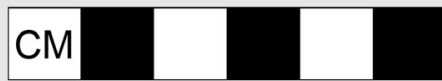

Fig. 6 An example of a well-preserved "Kreuzer or krajcár" (a) recovered elsewhere, and the two coins recovered from our burials ( $b$ Nyárlorrinc, burial no. 14426; c Nyárlőrinc, burial no. 10662)

\section{Results}

Osteometrical data, calculated body lengths, and ages at death are presented in Table 2.

Among the remains of no. 14426 (Fig. 3), the right forearm (Fig. 4) and mainly some skin from the dorsal area were mummified (Fig. 5). No cranial elements were found except for the right side of the mandible. Big green-colored patches can be seen on some vertebrae, both radii, ulnae, ilia, femora, tibiae, and elements of the feet on both sides. The green color must derive from the strongly corroded copper coin found next to the remains.

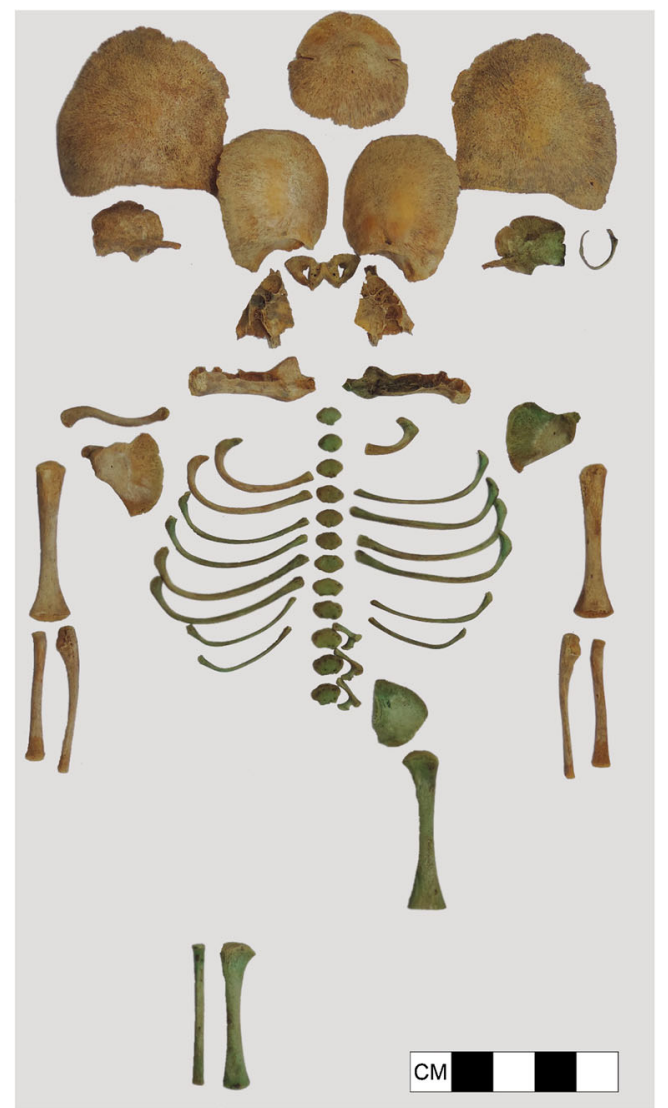

Fig. 7 Nyárlörinc, ind. no. 10662, cranial and postcranial elements. Some bones show green coloration from the coin offering

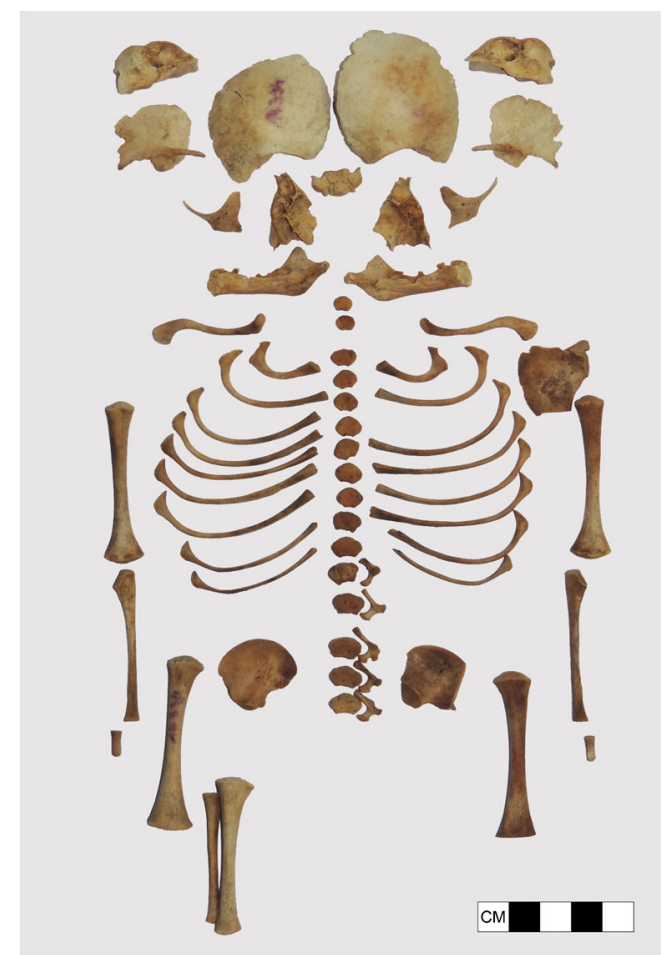

Fig. 8 Nyárlőrinc, ind. no. 14334, cranial and postcranial elements. No green coloration is visible; coin offering was not recovered

On the basis of the bone dimensions, the age at death of the mummified pre-term individual was $6.5-7$ lunar months. The body might have been approx. $28-35 \mathrm{~cm}$ long and weighed 0.4-0.91 kg. Our examination revealed no disease-related symptoms in the remains.

The ceramic pot that the individual was buried in (Fig. 2) was $18.9 \mathrm{~cm}$ in height and $53.6 \mathrm{~cm}$ in circumference (maximum) with a volume of $2700 \mathrm{~cm}^{3}$. These dimensions correspond to the ethnographical definition of a pot ("fazék") by Igaz and Kresz (1965). Similar vessels have been typically used since the eighteenth century CE (Lajkó 2015). No traces of glazing or other coating was present on the inner surface of the pot as an otherwise possible source of copper. According to our $\mu \mathrm{XRF}$ measurement, the strongly corroded copper coin ("krajcár", Fig. 6) contained $99.6 \% \mathrm{Cu}$, with Zn $(0.207 \%)$, $\mathrm{Ni}(0.171 \%)$, and $\mathrm{Fe}(0.030 \%)$ contaminants. Compared to the nominal weight of the "krajcár," this particular coin lost $0.7633 \mathrm{~g}$ due to the corrosion, $26.37 \%$ of its original weight.

Table $3 \mathrm{Cu}$ concentration of bone in dry weight \% (ICP-AES)

\begin{tabular}{llll}
\hline $\begin{array}{l}\text { Tested } \\
\text { specimen }\end{array}$ & $\begin{array}{l}\text { Nyárlőrinc } \\
14426\end{array}$ & $\begin{array}{l}\text { Nyárlőrinc } \\
10662\end{array}$ & $\begin{array}{l}\text { Nyárlőrinc } \\
14336\end{array}$ \\
\hline Scapula & 0.066 & 0.930 & 0.00517 \\
Femur & 3.140 & 1.740 & 0.00435 \\
Ileum & 3.994 & 3.331 & 0.00669 \\
\hline
\end{tabular}


Fig. 9 The picture in the top left corner designates the areas ( $a$ to d) investigated by $\mu \mathrm{XRF}$ in the Nyárlörinc, ind. no. 14426 item. Inserts $\mathbf{a}-\mathbf{d}$ show the found distribution of $\mathrm{Cu}$ in the respective areas, such as a the left femur, $\mathbf{b}$ the right palm, $\mathbf{c}$ the right forearm (radius, ulna), and $\mathbf{d}$ three lumbar vertebrae. The intensity of red color in the $\mu \mathrm{XRF}$ images correlates with the $\mathrm{Cu}$ concentration on the surface of the sample
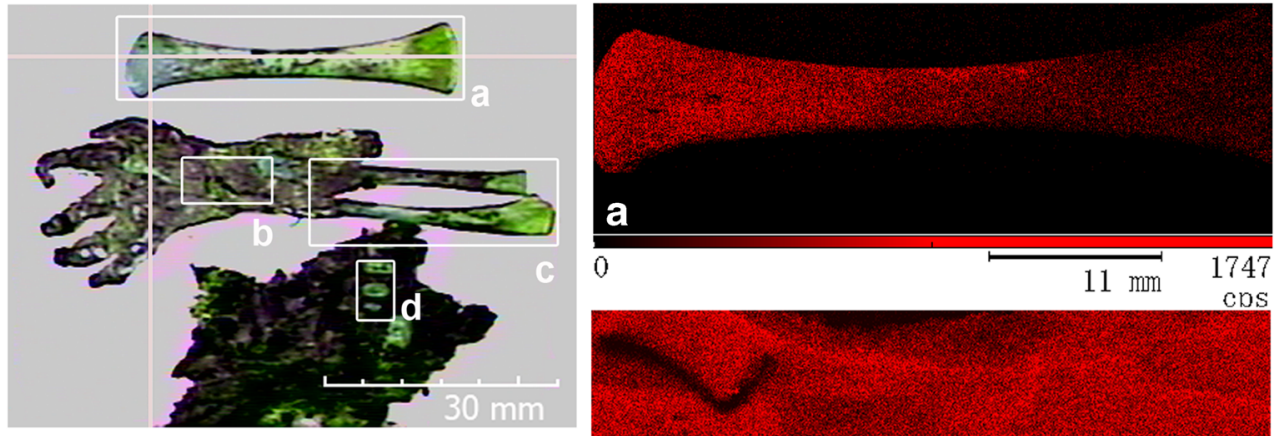

0

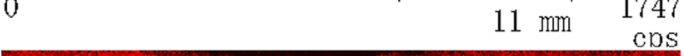

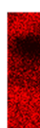
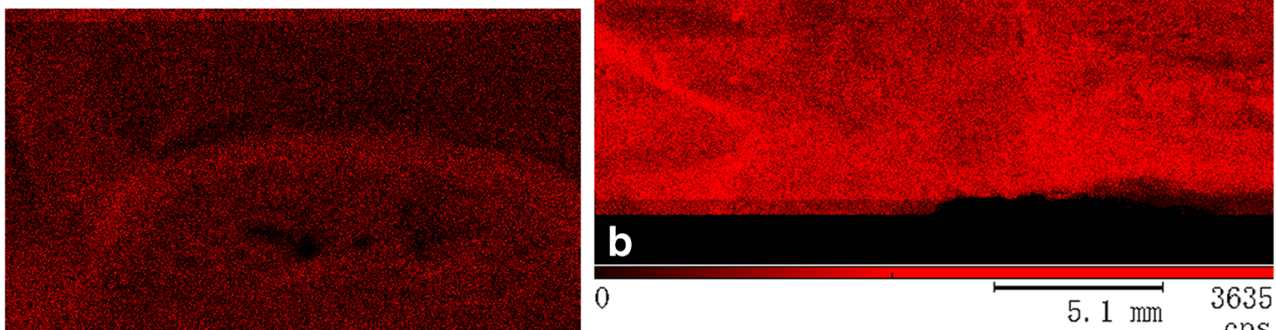

d

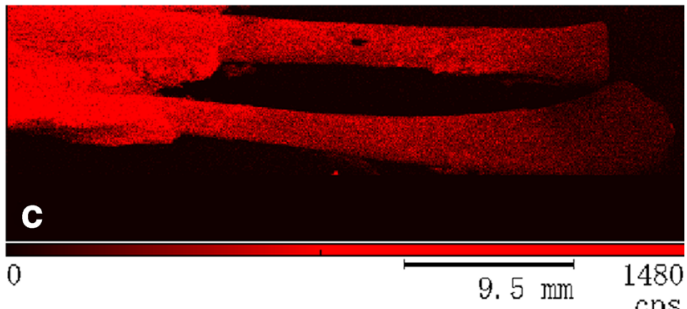

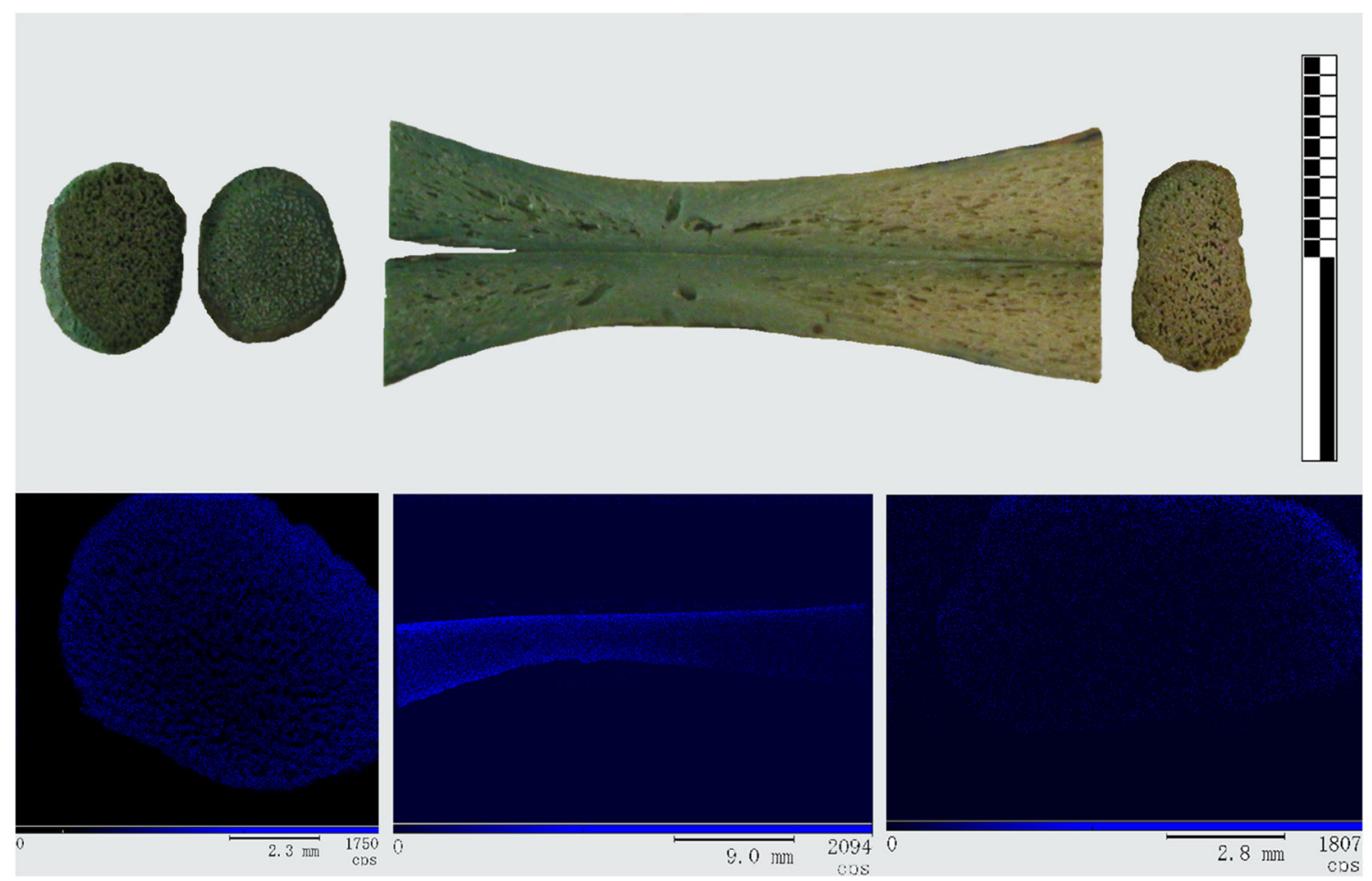

Fig. 10 A visual image of (top) and $\mathrm{Cu}$ distributions measured by $\mu \mathrm{XRF}$ (bottom) in the longitudinal and cross sections of the left femur of the Nyárlörinc, ind. no. 14426 item. The intensity of blue color in the $\mu \mathrm{XRF}$ images correlates with the $\mathrm{Cu}$ concentration. Please note that the $\mathrm{Cu}$ distribution found by $\mu \mathrm{XRF}$ shows the same pattern as the green $\mathrm{Cu}$ decoloration in the visual image of the bone sections 
Fig. 11 The picture in the top left corner designates the area investigated by $\mathrm{X}$-ray imaging and $\mu \mathrm{XRF}$ in the Nyárlörinc, ind. no. 14426 item. $\mathbf{c}$ the $\mathrm{X}$-ray image of the area, whereas $\mathbf{b}, \mathbf{d}, \mathbf{e}, \mathbf{f}$ the $\mathrm{Ca}, \mathrm{Fe}, \mathrm{P}$, and $\mathrm{Cu}$ distributions as measured by $\mu \mathrm{XRF}$. The intensity of the artificial coloring, identified at the bottom of each $\mu$ XRF image, correlates with the surface concentration of the respective element
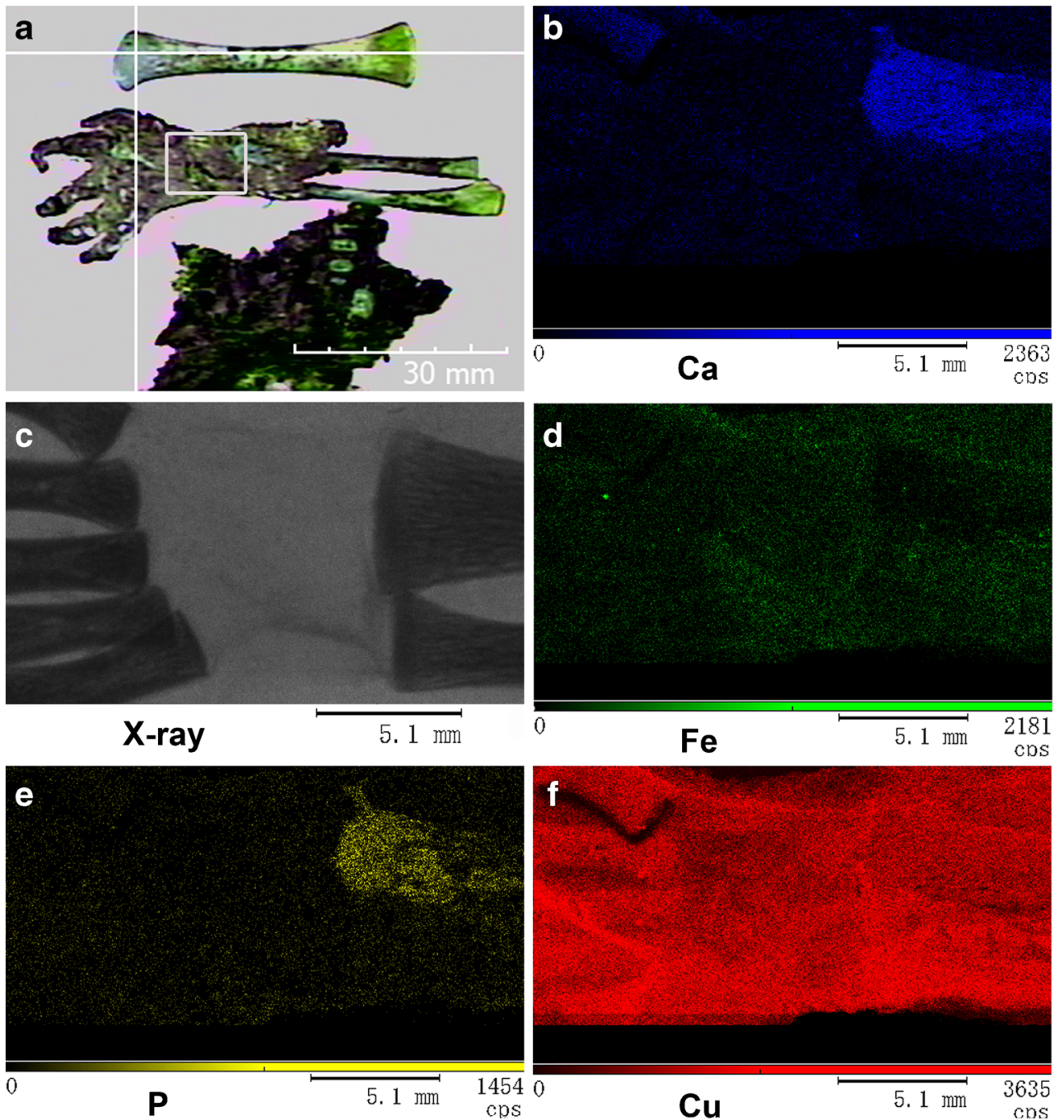

The remains of ind. no. 10662 are skeletonized showing green coloration on the vertebrae, costae, and left side of the body (temporale, mandible, ilium, femur, tibia, fibula) (Fig. 7). Age at death of the pre-term individual was 5.5-6.5 lunar months, the body might have been approx. $26-32 \mathrm{~cm}$ long and weighed $0.32-0.620 \mathrm{~kg}$. The remains were also found in a ceramic pot with a copper coin, but the vessel cannot be reconstructed, and the release date of the coin is also indecipherable (Fig. 6) since their state of preservation was very bad.

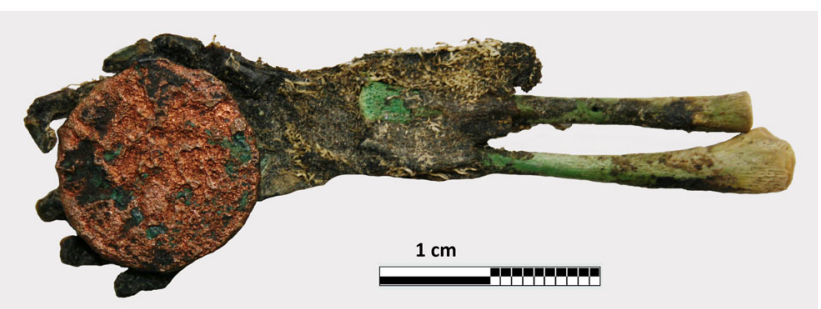

Fig. 12 Nyárlorinc, ind. no. 14426, right forearm with the copper coin in the palm
In the case of individual no. 14334, no green coloration can be seen on the skeletonized bones (Fig. 8). Age at death was 7.5-8.5 lunar months; the body might have been approx. 35$42 \mathrm{~cm}$ long and weighed $0.77-1.94 \mathrm{~kg}$. Ceramic pot or copper coin was not recovered in the burial.

The copper concentrations found using ICP-AES in greencolored and normal bones of no. 14426 (mummified + pot + coin) were compared with copper concentrations found in no. 10662 (skeletonized + pot + coin) and no. 14336 (skeletonized - no pot - no coin). The mummified forearm was too small and brittle to be sampled, so we only analyzed identifiable skeletonized parts instead. The measured data are summarized in Table 3.

$\mathrm{Cu}$ concentration in the remains of ind. no. 14426 was mapped using $\mu \mathrm{XRF}$ analysis in surfaces of mummified parts (Fig. 9), longitudinal and cross-sections (Fig. 10) of green bones.

Besides mapping element concentrations, $\mu \mathrm{XRF}$ analysis is also suitable for differentiating between soft and bony tissues of the mummified body parts: $\mathrm{P}$ and $\mathrm{Ca}$ 
distributions in the X-ray picture clearly outline the shape of the bones within the organic mass of the remains (Fig. 11). In our current paper, however, we are only analyzing $\mathrm{Cu}$ values in detail.

We have sampled the dry soil sediment containing the ceramic pot of burial no. 14426 and measured the $\mathrm{Cu}$ concentration three times ranging from 38.96 to $79.21 \mathrm{ppm}$ with an average of $55.05 \mathrm{ppm}$. This value corresponds to the usual average $\mathrm{Cu}$ concentration in the soil (Adriano 2001). This means that high $\mathrm{Cu}$ content of the remains is not a result of high background concentration.

$\mathrm{Cu}$ concentrations tend to be the highest in the mummified remains buried with a copper coin (no. 14426), values measured in the skeletonized remains buried with a coin (no. 10662) tend to be intermediate, and values of the skeletonized remains buried without a copper coin (no. 14336) are the lowest. $\mathrm{Cu}$ concentrations within the remains of one individual tend to be the highest in the ilium (possibly in the closest proximity of the coin), lower in the femur and scapula. Within bones of the lower limb, proximal epiphyses show higher concentrations than the distal epiphyses, and external surfaces also contain more $\mathrm{Cu}$ than the inside of bones.

\section{Discussion and conclusion}

Resources of fetal osteology usually address the issues of the status of these premature individuals (Fazekas and Kósa 1978; Kósa 1989; Scheuer and Black 2000; Baker et al. 2005; White and Folkens 2005; Huxley 2010; Barfield 2011). Depending on the clinical, forensic, or bioarcheological context, these works try to categorize pre-term human remains considering gestational age, developmental phase, measurements, and whether the child was viable or stillborn. But these works usually also acknowledge that the lack of any of these type of information may make it impossible to determine the status of the remains.

In our three cases, not a single bone element of the three children shows an age at death older than 8.5 lunar months. This means all three children were underdeveloped for a normal birth and they were not buried together with their mothers so we are presumably seeing a pre-term birth in all three cases. However, neither the remains nor the archeological context provides any sufficient data to unequivocally determine the status of these very young individuals. Even though they were definitely born older than 20 lunar months, we do not know whether they were born dead or alive, stillborn or neonate. We are only sure that they definitely fall in some of the categories for perinatal death described by Barfield (2011). However, on the basis of what we know about the chances of survival as a preterm neonate before the twentieth century, it is very likely all three of them died a couple days the latest after their preterm birth.

The fate of stillborn babies and perinate or neonate deaths can follow different paths. According to ethnographical references (Pintér 1891; Bartucz 1928; Habenstein and Lamers 1960; Selmeczi 1983), newborns who died without being baptized were rolled up in some sort of textile and buried in a pot (for example a milk-jug) or a small wooden box in abandoned cemeteries usually located close to ruins of medieval churches. Occasionally, low-value coins were put next to the body as offerings; the coins were intended to facilitate the soul's admission to heaven or served to pay the fee on the way to the underworld or Saint John the Baptist for christening the deceased in heaven (Dömötör 1990; Selmeczi 1992). However, prior to this investigation, such traditions have not been documented in the archeological or osteological record in Hungary.

Literature references for $\mathrm{Cu}$ concentrations of mummified human remains range from 2.3 to $23.8 \mathrm{ppm}$ (see references in Table 1). In contrast with this, the $66.9 \mathrm{ppm}$ value of our nocoin perinate (no. 14336) is almost three times higher than the upper limit of the reference range. In the presence of a copper coin, the skeletonized perinate (no. 10662) showed concentrations 495 times higher than those of the no-coin perinate, while the mummified individual (no. 14426) showed 497 times higher values.

Higher-than-background $\mathrm{Cu}$ concentration of the individual without coin (no. 14336) may simply be explained by the fact that remains of children younger than 3 years of age tend to show multiple times higher $\mathrm{Cu}$ values than adults (Lambert et al. 1979). Several hundred times higher $\mathrm{Cu}$ values than average may be related to the corrosion of the coins included in the burials. Since $\mathrm{Cu}$ concentration of the soil sample is normal, and the examinable vessel (that of burial no. 14426) had no glazing or coating possibly containing copper, mummification must have been facilitated by copper deriving from the "krajcár" coin.

$\mathrm{Cu}$ distribution in the remains is, however, far from even. Differences of concentration must be in connection with the actual localization of the coin within the burial. Body parts in the closest proximity will show the highest concentrations and possibly (but not necessarily) a better level of preservation too. This is why the scapula of the non-mummified individual Nyárlörinc no. 10662 shows a higher concentration than the scapula of the mummified Nyárlörinc no. 14426. In case of individual no. 10662, the coin might have been located near the scapula. In the case of individual no. 14426, posture of the fingers and very high $\mathrm{Cu}$ concentration values around the hip refer to a copper coin having been placed in the right palm. Nearby soft tissues (right hand and forearm, lower trunk, hips) were possibly exposed to the highest level of copper infiltration in the entire study resulting in quasi-natural mummification of the affected body parts. As we move further away from 
the corroded copper coin, superficial copper concentrations gradually decrease in the remains. The same is observed in the longitudinal and cross sections of bones: the closer proximity to the coin, the higher is the copper concentration, and bone surfaces always show higher concentration than the inside of bones. These phenomena imply that individual no. 14426 was surrounded by a moist microenvironment in the pot, where gradual diffusion of soluble copper originating from the coin was facilitated for a longer period of time, and this relatively isolated setting did not allow complete decay of the little dead body.

Even though our comparative measurements show that high copper concentration in the microenvironment alone is not sufficient for complete mummification processes (consider the non-mummified individual no. 10662), a major cause of the mummification of individual no. 14426 was still the corrosion of the copper coin being placed next to the corpse in an almost closed ceramic vessel.

Copper as a mummifying agent is also rarely mentioned in the worldwide literature. Even the mummification process of the famous "Copper Man" found in the hyperarid Atacama Desert is mostly attributed to desiccation, and copper ions had not penetrated soft tissues of the body beyond the depth of the skin (Aufderheide 2003).

In contrast to this, our findings show copper concentrations in the inside of the bones several hundred times higher than normal. Despite the well-known antimicrobial and promummification character of this element, copper-driven quasi-natural mummification has not been documented in the international osteoarchaeological literature. Our perinate individual buried with a copper coin in the palm (Fig. 12) gives a unique yet expressive example of this process. The Nyárlörinc perinate burial no. 14426 may be the first copper-driven mummification case ever reported, and hopefully, more cases are to appear in the future.

The analytical techniques applied in these perinatal cases (ICP-AES, $\mu \mathrm{XRF}$ ) are a novelty in the osteoarcheological routine; thus, we hope our data will furnish new information in Central European subadult osteoarcheology.

\section{References}

Adriano DC (2001) Trace elements the terrestrial environment. Springer, New York

Aufderheide AC (2003) The scientific study of mummies. Cambridge University Press, Cambridge

Baker BJ, Dupras TL, Tocheri MW (2005) The osteology of infants and children. Texas A\&M University Press, USA

Balázs J (2005) Paleopatológiai vizsgálatok egy XII-XVI. századi széria (Nyárlőrinc Hangár út) leletein. Diplomawork, University of Szeged, Department of Biological Anthropology

Balázs J, Bölkei Z (2007) Partly mummified foetus. VI World Congress on Mummy Studies Program and Abstracts, 277
Balázs J, Bölkei Z, V Székely G (2005) A Nyárlőrinc Hangár utcai széria embertani feldolgozásának eredményei. Cumania 21:57-82

Balázs J, Zádori PG, Vandulek C, Molnár E, Ősz B, Bereczki Z, Paja L, Palkó A, Fogas O, Zink A, Nerlich A, Pálfi G (2015) Morphological and paleoradiological studies of Pott's disease cases. Acta Biol Szeged 59(2):211-216

Barfield WD (2011) Clinical reports - standard terminology for fetal, infant, and perinatal deaths. Pediatrics 128:177-181

Bartucz L (1928) Köcsögbe temetés a régi palócoknál. Antropológiai Füzetek. Anthropol Hung III(1-3):19-21

Beckhoff B, Kanngießer B, Langhoff N, Wedell R, Wolff H (eds) (2006) Handbook of practical X-ray fluorescence analysis. Springer, Berlin

Benfer RA, Typpo JT, Gaff GB, Pickett EE (1978) Mineral analysis of ancient Peruvian hair. Am J Phys Antropol 48:277-282

Bochkor Á (1960) A Szent Jobb orvosi szemmel. Vigilia 1960(08):492_ 494

Bölkei Z (2005) Embertani vizsgálatok egy középkori széria (Nyárlőrinc Hangár út) leletein. Diplomawork, University of Szeged, Department of Biological Anthropology

Carvalho ML, Casaca C, Pinheiro T, Marques JP, Chevallier P, Cunha AS (2000) Analysis of human teeth and bones from the chalcolithic period by X-ray spectometry. Nucl Inst Methods Phys Res B 168: $559-565$

Cockburn A, Cockburn E, Reyman TA (1998) Mummies, disease \& ancient cultures, 2nd edn. Cambridge University Press, Cambridge

Degryse P, Muchez P, De Cupere B, Van Neer W, Waelkens M (2004) Statistical treatment of trace element data from modern and ancient animal bone: evaluation of roman and byzantine environmental pollution. Anal Lett 37(13):2819-2834

Dömötör T (1990) Temetkezési szokások. In: Hoppál M (ed) Magyar Néprajz VII: népszokás, néphit, népi vallásosság. Akadémiai Kiadó, Budapest, pp 7-67

Farkas G (1972) Antropológiai Paraktikum I. Paleoantropológiai metodikák. József Attila Tudományegyetem, Szeged

Fazekas G, Kósa F (1978) Forensic fetal osteology. Akadémiai Kiadó, Budapest

Goffer Z (2007) Archaeological chemistry. Wiley, Hoboken

Habenstein RW, Lamers WM (1960) Funeral customs the world over. Bulfin Printers, Milwaukee

Huxley AK (2010) Estimation of age from fetal remains. In: Latham KE, Finnegan M (eds) Age estimation of the human skeleton. Charles $\mathrm{C}$ Thomas Publisher, Sringfield, pp 147-160

Igaz M, Kresz M (1965) A népi cserépedények szakterminológiája. Néprajzi Értesítő 47:87-131

Józsa L (2006) Paleopathologia. Elődeink betegségei. Semmelweis Kiadó, Budapest

Kłys M, Lech T, Zieba-Palus J, Białka J (1999) A chemical and physicochemical study of an Egyptian mummy 'Iset Iri Hetes' from the Ptolemaic period III-I B.C. Forensic Sci Int 99(3):217-228

Kósa F (1989) Age estimation from the foetal skeleton. In: Işcan MY (ed) Age markers in the human skeleton. Charles C. Thomas Publisher, Springfield, pp 21-54

Kristóf LA (2015) Paleoradiológia: non-invazív módszertani lehetőség a történeti antropológiában. Doctoral Thesis, University of Szeged, Doctoral School in Biology

Lajkó O (2015) Cserepén ismerem, minemü fazék volt... Adatok a kora újkori edénymúvesség és a magyar népi kerámia eredetének kutatásához. Móra Ferenc Múzeum, Szeged

Lambert JB, Szpunar CB, Buikstra JE (1979) Chemical analysis of excavated human bone from middle and late Woodland sites. Arheometry 21(2):115-129

Lynnerup N (2007) Mummies. Yearb. Phys Anthropol 50:162-190

Marcsik A, Molnár E, Szathmáry L (2006) The antiquity of tuberculosis in Hungary: the skeletal evidence. Mem I Oswaldo Cruz 101(2):67-71 
Molnár E, Dutour O, Pálfi G (1998) Diagnostic paléopathologique des tréponématoses: à propos d'un cas bien conservé. Bull Mém Soc Anthrop Paris 1-2(10):17-29

Nunnelley LL, Smythe WR, Trish JHV, Alfrey AC (1976) Trace elements analysis of tissue and resin from Egyptian mummy PUM II. Paleopathol Newsl 12:12-14

Pálfi G, Panuel M, Molnár E (1997) Paleoradiologic study of a 17th century case of treponematosis (Nyárlörinc, Hungary). Acta Biol Szeged 42:113-122

Pálfi G, Zádori P, Balázs J, Vandulek C, Kelemen K, Molnár E, Ösz B, Palkó A (2009) Paleoradiological studies of cases of Pott's disease. In: Pálfi G, Molnár E, Bereczki Z, Pap I (eds) Des lésions du passé aux diagnostics modernes. University Press, Szeged, pp 102-103

Pap I, Susa É, Józsa L (1997) Mummies from the 18-19th century Dominican Church of Vác, Hungary. Acta Biol Szeged 42:107-112

Pintér S (1891) A palócz születése, házassága és halálozása. Ethnographia 2:99

Quigley C (1998) Modern mummies: the preservation of the human body in the twentieth century. McFarland Publishers, Jefferson

Rácz P (2013) Szent István ereklyéi. Rubicon 2014(6):21-25

Reyman TA, Barroco RA, Cockburn TA (1976) Histopathological examination of an Egyptian mummy. Bull N Y Acad Med 52:506-516

Sandford MK, Kissling GE (1994) Multivariate analyses of elemental hair concentrations from a medieval Nubian population. Am J Phys Anthropol 95(1):41-52
Sanford MK, Van Gerven DP, Meglen RR (1983) Elemental hair analysis: new evidence on the etiology of cribra orbitalia in Sudanese Nubia. Hum Biol 55:831-844

Scheuer L, Black S (2000) Developmental juvenile osteology. Elsevier Academic Press, London

Selmeczi L (1983) Négyszállási adatok a kereszteletlen gyerek eltemetéséhez. NyJAMÉ 24-26:177-180

Selmeczi L (1992) Régészeti - néprajzi tanulmányok a jászokról és a kunokról. Folkl Etnográfia 64:227-239

Shafer MM, Siker M, Overdier JT, Ramsl PC, Teschler-Nicola M, Farrell PM (2008) Enhanced methods for assessment of the trace element composition of Iron Age bone. Sci Total Environ 401(1-3):144-161

Susa É, Józsa L (1995) A múmiakészítés technikája és eredményei a kezdetektől napjainkig. Anthrop Közl 37:45-60

Szpunar CB, Lambert JB, Buikstra JE (1978) Analysis of excavated bone by atomic absorption. Am J Phys Anthrop 48:199-202

Unger E (1997) Magyar éremhatározó - Ungarischer Münzbestimmer. Magyar Éremgyűjtők Egyesülete, Ajtósi Dürer Könyvkiadó, Budapest

V Székely G (1987) Kun eredetű tárgyak és kulturális elemek Nyárlőrinc középkori temetőjében. Kézirat. Katona József Múzeum, Kecskemét

White TD, Folkens PA (2005) The human bone manual. Elsevier Academic Press, San Diego

Zlateva B, Djingova R, Kuleff I (2003) On the possibilities of ICP-AES for analysis of archaeological bones. Cent Eur J Chem 1(3):201-221 